TITLE:

\title{
Hydrolysis behavior of various crystalline celluloses treated by cellulase of Tricoderma viride
}

$\operatorname{AUTHOR}(\mathrm{S})$ :

Abdullah, Rosnah; Saka, Shiro

\section{CITATION:}

Abdullah, Rosnah ... [et al]. Hydrolysis behavior of various crystalline celluloses treated by cellulase of Tricoderma viride. Cellulose 2014, 21(6): 4049-4058

ISSUE DATE:

2014-08-26

URL:

http://hdl.handle.net/2433/198675

\section{RIGHT:}

The final publication is available at Springer via http://dx.doi.org/10.1007/s10570-0140410-4.; 許諾条件により本文ファイルは2015-08-26に公開.; This is not the published version. Please cite only the published version.; この論文は出版社版でありません。引用 の際には出版社版をご確認ご利用ください。 


\section{Hydrolysis behavior of various crystalline celluloses}

2 treated by cellulase of Tricoderma viride

3

4 Rosnah Abdullah and Shiro Saka*

5

6 Department of Socio-Environmental Energy Science,

7 Graduate School of Energy Science, Kyoto University,

8 Yoshida-honmachi, Sakyo-ku 606-8501, Kyoto, Japan

9

10

*Shiro Saka

11 Tel/Fax: +81(0)75 7534738

12 Email address: $\underline{\text { saka@energy.kyoto-u.ac.jp }}$ 


\section{Abstract}

30 Cellobiose and glucose are valuable products that can be obtained from enzymatic hydrolysis of cellulose. This

31 study discusses changes in the crystalline form of celluloses to enhance the production of sugars and examines the effect on structural properties during enzymatic hydrolysis. Various crystalline celluloses consisting of group I (cell I, cell III , cell $\mathrm{IV}_{\mathrm{I}}$ ) and group II (cell II, cell III II, cell $\mathrm{IV}_{\mathrm{II}}$ ) of similar DPs were prepared as starting materials. The similar DP values allowed a more direct comparison of the hydrolysis yields. The outcomes were analyzed and evaluated based on the residues and supernatants obtained from the treatment. As a result: 1) action of the cellulase of Trichoderma viride decreased both DP and crystallinity, with greater changes in group II celluloses, 2) the polymorphic interconversion process that occurred for cell $\mathrm{III}_{\mathrm{I}}$, cell IV $\mathrm{I}_{\mathrm{I}}$, cell $\mathrm{III}_{\mathrm{II}}$ and cell $\mathrm{IV}_{\mathrm{II}}$ during the treatment was independent of the enzymatic hydrolysis, thus, the hydrolysis behaviors depended on the starting material of the celluloses, and 3) higher sugar production was obtained from cell $\mathrm{III}_{\mathrm{I}}$ and group II. Therefore, the hydrolysis behavior of the various crystalline celluloses depended on the particular polymorph of 41 the starting material. 
As cellulose is a main component of plant cell walls and the most abundant polymer in nature, its exploitation for biofuels, particularly bioethanol, has become a major research focus worldwide (O'sullivan 1997; Schacht et al. 2008). By the process of saccharification, glucose, cellobiose and other sugars can be obtained from cellulose. Those small sugars can be fermented to produce ethanol (Ward 2011). Thus, a conventional sequence that has been practised widely, is that to treat lignocelluloses with acid/alkali or sub/supercritical water, and/or later followed by enzymatic hydrolysis (Hsu 1996; Kumar et al. 2010).

Enzymatic hydrolysis of cellulose is a slow process and the extent of hydrolysis is influenced by structural properties such as crystallinity, surface area, DP, etc (Fan et al. 1980; Lee et al. 1983; Yoshida et al. 2008; Hall et al. 2010). Native cellulose is composed of $\beta$-D-glucopyranose units linked together in linear chains by $\beta-1,4$-glucosidic bonds, forming a crystalline material. Most practical cellulose samples appear to contain both crystalline and amorphous cellulose (Andersson et al. 2003; Igarashi et al. 2006). Completely disordered or amorphous cellulose could be hydrolyzed at a much faster rate, thus, knowledge of the initial degree of crystallinity is essential for pre-determining the enzymatic digestibility of a cellulose sample.

Modifying cellulose structure could be a useful way to enhance the accessibility of cellulose for enzymatic hydrolysis (Weimer et al. 1991). Treatments with strong alkali or primary amines caused both delignification and conversion of native cellulose I to other forms. This results in the formation of different crystalline cellulose allomorphs that have different unit cell dimensions, chain packing schemes and hydrogen bonding relationships (Lokhande et al. 1977; Nishimura and Sarko 1987; Isogai and Atalla 1998; Langan et al. 2001; Wada et al. 2004). To date, six crystalline cellulose allomorphs (I, II, IIII, IIIII, IV identified by their characteristic X-ray diffraction (XRD) patterns and solid-state ${ }^{13} \mathrm{C}$ nuclear magnetic resonance spectra.

Numerous studies in recent decades involving cellulase on cellulose have revealed the mechanisms by which the enzyme degrades cellulose (Sulzenbacher et al. 1997; Divne et al. 1998; Cao and Tan 2002). Different types of cellulases changed the DP, the solubility in aqueous alkali and cystallinity after hydrolysis (Reese et al. 1957; Sasaki et al. 1979; Puri 1984). Cellobiose yield was increased by using non-continuous hydrolysis process without further addition of enzyme (Vandergherm et al. 2010), while treated cellulose samples with alkali or anhydrous liquid ammonia affected enzyme digestibility based on the relative crystallinities (Mittal et al. 2011).

In the present work, the behavior of various crystalline celluloses allomorphs is examined and their effects were compared. There are only a few studies on the effects of polymorphy on hydrolysis of cellulose by enzymes. However, they focussed on either one or a few allomorphs, explored their kinetics, studied their molecular simulations and used bacteria for their treatment (Weimer et al. 1991; Wada et al. 2010; Beckham et al. 2011; Mittal et al. 2011). To the best of the authors' knowledge, no reports are yet available that compares enzymatic hydrolysis behavior of various crystalline celluloses with retention of constant DP. Therefore, in this study, hydrolysis behavior of the various crystalline celluloses during treatment by cellulase of Trichoderma viride is investigated. 


\section{Materials and Methods}

\section{Various crystalline cellulose and enzyme}

Cotton linters (Buckeye 1AY-500) were used to prepare various crystalline cellulose samples according to the previous study (Abdullah et al. 2013). Briefly, cotton linters in their native state have the cellulose I (cell I) structure. Cellulose II (cell II) was prepared by mercerization using aqueous $\mathrm{NaOH}$. Celluloses III I $_{\text {( }}\left(\mathrm{Cell}_{\mathrm{III}}\right.$ ) and III $_{\text {II }}\left(\right.$ cell III $_{\text {II }}$ ) were acquired from cell I and cell II, respectively, by using ethylenediamine treatment, while celluloses $\mathrm{IV}_{\mathrm{I}}\left(\right.$ cell $\mathrm{IV}_{\mathrm{I}}$ ) and $\mathrm{IV}_{\mathrm{II}}\left(\right.$ cell $\mathrm{IV}_{\mathrm{II}}$ ) were obtained from the prepared cell $\mathrm{III}_{\mathrm{I}}$ and cell $\mathrm{III}_{\mathrm{II}}$ samples by using glycerol treatment at $260{ }^{\circ} \mathrm{C} / 0.6 \mathrm{MPa}$ for $30 \mathrm{~min}$.

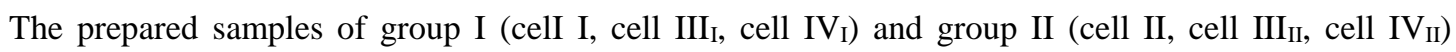
celluloses were then adjusted by trial and error to give a common degree of polymerization (DP) by changing the treatment conditions mentioned above for converting cell I to various forms of celluloses. All these samples were found to contain similar components of $99.9 \mathrm{wt} \%$ glucose and $0.1 \mathrm{wt} \%$ xylose (TAPPI 1988).

The cellulase in lyophilized powder from Trichoderma viride Sigma C9422 was purchased from Nacalai Tesque, Japan. The activity of the enzymes was expressed in international units (U), i.e., one international unit of enzyme is defined as the amount that catalyzes the formation of one $\mu$ mol of product per min under the defined conditions. The activity was found to be $11.4 \mathrm{U} / \mathrm{ml}$.

\section{Enzymatic hydrolysis of cellulose}

In a $20 \mathrm{ml}$ glass vials were added $35 \mathrm{mg} / \mathrm{ml}$ cellulose, $0.35 \mathrm{U} / \mathrm{mg}$ cellulose of cellulase and $0.05 \mathrm{M}$ sodium acetate buffer of $\mathrm{pH} 5.0$ (thermostated before at $50^{\circ} \mathrm{C}$ ) until $3 \mathrm{ml}$ final volume. The pH value was adjusted using $1 \mathrm{M}$ hydrochloric acid $(\mathrm{HCl})$, if necessary (Bommarius et al. 2008). The controls together with the reaction mixtures were placed in an incubator at $50{ }^{\circ} \mathrm{C}$ and continuously stirred using magnetic stirrers. No $\beta$-glucosidase supplement was used in this study (Kadam et al. 2004). At the designated treatment times, the samples were removed and the enzyme reactions were terminated by quenching in ice bath, followed by centrifugation at $8000 \times g$ for $2 \mathrm{~min}$. The supernatant was immediately filtered, then refrigerated until subjected to analysis (Wyk 1997; Bommarius et al. 2008; Yang 2010).

\section{Analyses of cellulose residue}

Degree of polymerization (DP) - The molecular weight distribution of various celluloses was evaluated using phenyl carbamate derivatives. The procedure was modified from previously published methods (Evans et al. 1989, Mormann and Michel 2002). Cellulose (5 mg) and phenyl isocyanate $(0.2 \mathrm{~mL})$ were added to pyridine (2 mL), and its mixture was heated up to $80{ }^{\circ} \mathrm{C}$ under continuous stirring for $24 \mathrm{~h}$ to become a yellow transparent solution. Methanol $(0.5 \mathrm{~mL})$ was then added to terminate the reaction, and the solvent was removed by evaporation in vacuum to give dark yellow syrup.

The syrups of the phenyl carbamate derivatives were dissolved in tetrahydrofuran (THF). The solutions were then filtered through $0.45 \mu \mathrm{m}$ microcentrifuge membrane filters prior to analysis by gel permeation chromatography (GPC) Shimadzu LC-10A under the following chromatographic conditions: column, Shodex 
130 LF-804; column temperature, $40{ }^{\circ} \mathrm{C}$; eluent, HPLC grade THF; flow-rate, $1.0 \mathrm{ml} / \mathrm{min}$ and detector, $\mathrm{UV}_{254 \mathrm{~nm}}$.

131 Polystyrene standards were used to calibrate retention time for its molecular weight. The DP of cellulose was

132 then calculated by dividing the molecular weights of the carbanilated cellulose by that of its repeating unit

133 (=519) with the degree of substitution of 3.0. All reported values were based on the average of duplicate 134 samples.

135 Crystallinity - The crystallinity was evaluated by using the X-ray diffraction (XRD) patterns that were 136 recorded by X-ray diffractometer Rigaku RINT 2200 equipped with monochrometer. X-ray diffraction was 137 conducted on reflectance modes through $7.5^{\circ} \leq 2 \theta \leq 32.5^{\circ}$ by $\mathrm{Cu}-\mathrm{K}_{\alpha}$ radiation, operated at $40 \mathrm{kV}$ and $30 \mathrm{~mA}$.

138 The cellulose sample was placed on a glass sample holder and flattened carefully, then mounted on the sample 139 holder. Cellulose crystallinity was measured by deconvolution method as previously reported (Park et al. 2010).

140 The XRD patterns were also simulated by using Mercury program according to the previous reports (French 141 2013; French and Cintrón 2013, Abdullah et al. 2013) and the crystallinity was then calculated as above. The 142 crystallite size can be estimated according to its peak width at half maximum (pwhm) intensity by using 143 Scherrer Eq. (1) (French and Cintrón 2013).

$$
\tau=K \lambda /(\beta \cos \theta)
$$

145 In Eq. (1), $\tau$ is the crystallite size, $K$ is a constant depends on the crystal shapes, $\lambda$ is the wavelength of $\mathrm{Cu}-\mathrm{K}_{\alpha}$

$146=1.542 \AA, \beta$ is the pwhm in radians and $\theta$ is the diffraction angle. The value of the variable crystal shape factor $147 \quad K$ is unknown, thus, it is assumed as $K=1$

148 The decomposition rate of the cellulose allomorphs was in addition estimated using a typical curve149 fitting program, Origin.

\section{Analysis of supernatant}

Total sugars production - The total hydrolyzed products, cellobiose and glucose, in supernatant for each hydrolysis time points were measured by high performance liquid chromatography (HPLC) system 153 Shidmadzu, LC-10A. The chromatographic conditions were: column, Bio-Rad Aminex HPX-87P x 7.8 mm; 154 detector, $\mathrm{UV}_{254 \mathrm{~mm}}$; eluent, deionized water; flow-rate, $0.6 \mathrm{ml} / \mathrm{min}$ and oven temperature, $85{ }^{\circ} \mathrm{C}$. The sample injection volume was $10 \mu \mathrm{l}$ and the running time was $30 \mathrm{~min}$.

\section{Results and Discussion}

\section{Evaluation of cellulose residues}

The main aim of this experiment was to investigate the behaviors of various crystalline celluloses in enzymatic hydrolysis as the treatment medium. For this purpose, it is essential that the starting materials have similar DPs in order to evaluate and compare directly their hydrolysis behaviors. As a result, the adjusted DP by trial and error and the corresponding crystallinity of the celluloses are summarized in Table 1. The XRD patterns of these celluloses are illustrated in Fig. 1.

Each of these celluloses was then treated with cellulase at $\mathrm{pH} 5.0$ and $50{ }^{\circ} \mathrm{C}$ with solid concentration set

164 to $35 \mathrm{mg} / \mathrm{ml}$ and enzyme loading of $0.35 \mathrm{U} / \mathrm{mg}$ cellulose. As the substrate is pure cellulose, higher loading of 
166 presented in Fig. 2. During the 17 day hydrolysis treatment, the residue weights from these various celluloses are decreasing, with the highest rate during the first week. In group I, cell $\mathrm{III}_{\mathrm{I}}$ hydrolyzed the most, and it has lesser residue than that of cell I and cell $\mathrm{IV}_{\mathrm{I}}$, which behave quite similarly. On the other hand, all celluloses in group II reach more or less similar yields and are seemingly equivalent to those of cell $\mathrm{III}_{\mathrm{I}}$. Generally, group II celluloses are easier to hydrolyze than those of group I, except for cell $\mathrm{III}_{\mathrm{I}}$.

The rate of decomposition of the cellulose allomorphs was also estimated using Origin program and it was found that the rate of decomposition for cell $\mathrm{I}$, cell $\mathrm{III}_{\mathrm{I}}$ and cell $\mathrm{IV}_{\mathrm{I}}$ are $0.19,0.49$ and $0.21 \mathrm{wt} \%$ per day, respectively. While for group II celluloses, cell II, cell $\mathrm{III}_{\mathrm{II}}$, cell $\mathrm{IV}_{\text {II }}$ decomposed at $0.23,0.24$ and $0.30 \mathrm{wt} \%$ per day, respectively. From these estimations, it can be said that group I celluloses degraded slower than group II celluloses, except cell $\mathrm{III}_{\mathrm{I}}$.

Figure 3 shows the XRD patterns of group I celluloses after enzymatic hydrolysis. In Fig. 3 (left), residues from cell I remain almost unchanged even after 17 days hydrolysis treatment. However, the intensity at $2 \theta \approx 22.5^{\circ}$ is decreasing as enzymatic hydrolysis is prolonged, and the peaks at $2 \theta \approx 14.4^{\circ}$ and $16.3^{\circ}$ are not sharp as observed in the control. This is seen in the progressive decrease in crystallinity in Fig. 6 (below) and may be due to the enzymatic attacks on the structure of the cell I (Lee et al. 1983; Cao and Tan 2005).

In Fig.3 (middle), the XRD patterns of residues from cell $\mathrm{III}_{\mathrm{I}}$ demonstrate that the cell $\mathrm{III}_{\mathrm{I}}$ is slowly converted back to cell I. Yet, the full XRD pattern of cell I is not obtained. During the treatment, the residues from cell $\mathrm{III}_{\mathrm{I}}$ are observed to be gradually modified to a mixture of cell I and cell $\mathrm{III}_{\mathrm{I}}$. As for residues from cell $\mathrm{IV}_{\mathrm{I}}$, in Fig. 3 (right), no significant changes are observed, except for the peak at $2 \theta \approx 15.1^{\circ}$. In both cases, some enzymatic attack could also have taken place.

Figure 4 shows the XRD patterns of group II celluloses after enzymatic hydrolysis. Though there is no significant change observed for the XRD patterns of cell II in Fig 4 (left), the intensity at $2 \theta \approx 19.7^{\circ}$ and $22.0^{\circ}$ decreases as enzymatic treatment time is prolonged. The XRD patterns of residues from cell $\mathrm{IIII}_{\mathrm{II}}$ in Fig. 4 (middle) and cell IV $\mathrm{V}_{\text {II }}$ in Fig. 4 (right), were slowly converted into their parent, cell II.

For cell $\mathrm{III}_{\mathrm{II}}$ in Fig. 4 (middle), two peaks at $2 \theta \approx 20.1^{\circ}$ and $21.6^{\circ}$ emerge during the time of hydrolysis, comparable to the control, cell II. In contrast with Fig. 4 (right), the peak at $2 \theta \approx 15.1^{\circ}$ for cell $\mathrm{IV}_{\text {II }}$ disappears after a few days' treatment, replicating the control cell II. Thus, from cell III II in Fig. 4 (middle) and cell IV $_{\text {II }}$ in

193 Fig. 4 (right), mixtures comprising cell $\mathrm{III}_{\mathrm{II}}$ and cell II, also cell $\mathrm{IV}_{\mathrm{II}}$ and cell II, are present during the treatments. These behaviors of cellulose residues from cell $\mathrm{III}_{\mathrm{I}}$ in Fig. 3 (middle); cell IV $\mathrm{I}_{\mathrm{I}}$, in Fig. 3 (right); cell $\mathrm{III}_{\mathrm{II}}$, in Fig. 4 (middle) and cell IV $\mathrm{IV}_{\mathrm{II}}$, in Fig. 4 (right) were also examined under wet conditions by X-ray diffractometry with similar results.

Figure 5 shows XRD patterns of residues from cell IIII treated with and without enzyme. In these data, the changes from cell $\mathrm{III}_{\mathrm{I}}$ into cell I occur with or without cellulase. However, the peaks at $2 \theta \approx 14.4^{\circ}$ and $16.3^{\circ}$ appear at a much slower rate with enzyme. Somehow, the enzymatic attacks must interfere with the conversion process. According to the literature, immersion of cell $\mathrm{III}_{\mathrm{I}}$ in a polar solvent could result in cell $\mathrm{III}_{\mathrm{I}}$ or cell I (Loeb and Segal 1955; Wada et al. 2008). Similar conversion of the crystalline form to its parent cellulose is also detectable with cell $\mathrm{IV}_{\mathrm{I}}$, cell $\mathrm{III}_{\mathrm{II}}$ and cell $\mathrm{IV}_{\mathrm{II}}$, but is insignificant for cell $\mathrm{IV}_{\mathrm{I}}$, when it is treated without enzyme.

The simulation on XRD patterns based on previous studies (French 2013; French and Cintrón 2013, 
206 input pwhm seemed to match the experimental patterns (control celluloses) of both group I and group II

207 celluloses. Thus, Table 2 summarizes the crystallite size and crystallinity of various celluloses at the

208 corresponding input pwhm. The crystallite size and crystallinity of celluloses in group I is, respectively, seen to

209 be similar to and higher than that in group II celluloses.

210 The simulated patterns demonstrated similar crystallinity as in the experimental patterns. Since there

211 was no amorphous contribution to the Mercury simulation patterns, the amorphous part must have come from

212 the deconvolution method, which could be the consequences of assumptions used. Such assumptions are built

213 into the deconvolution routines, for examples: only the main peaks included in the deconvolution, the peak

214 shape used being Gaussian instead of pseudo-Voigt (as assumed in the Mercury) etc.

215 Figure 6 shows the relationship between DP and crystallinity the celluloses after enzymatic hydrolysis.

216 The crystallinity is observed to drop slowly after 1 day of treatment and then starts to decrease faster. The

217 enzyme could probably attack first the amorphous regions of the celluloses, hence the crystallinity dropped

218 slower at first, and then later would attack the crystalline parts. As for the DP, it is observed to decrease with

219 treatment time. With cellulose in the modified forms (cell $\mathrm{III}_{\mathrm{I}}$, cell IV $\mathrm{IV}_{\mathrm{I}}$, cell II, cell III II, cell $\mathrm{IV}_{\mathrm{II}}$ ), enzymatic

220 hydrolysis reaction is shown to be more effective, compared with the cellulose in the cell I form. This agrees

221 with previous work by Igarashi et al. (2007). This figure shows more changes occurred with group II than group

222 I celluloses, and the changes during hydrolysis reaction were closely related to the initial cellulose structure.

223 The relationship of DP and hydrolyzed cellulose of various celluloses after enzymatic hydrolysis is

224 illustrated in Fig. 7. More cellulose is hydrolyzed as the enzymatic hydrolysis is prolonged and the DP is

225 decreased, similar with the observation of Fig. 6.

\section{Evaluation of supernatant}

The analysis of supernatant shows that enzymatic hydrolysis produces hydrolyzed products (total sugar) such as cellobiose and glucose. On average, more than $75 \mathrm{wt} \%$ of the total sugar consists of glucose. The results on total sugar obtained for various celluloses after enzymatic hydrolysis are shown in Fig. 8. Overall, cell III and group II celluloses produced similar total sugar yields, higher than those of cell I and cell IV $_{\text {I. This }}$ confirms earlier findings that hydrolysis yield rates of cellulose $\mathrm{III}_{\mathrm{I}}$ were much higher than for cellulose I (Igarashi et al. 2007), but for a more complete range of polymorphs and controlled DP.

Moreover, in this work, comparable yields of total sugar are obtainable from enzymatic hydrolysis of cell II and cell $\mathrm{III}_{\mathrm{I}}$, disagreeing with the previous work in which similar DPs were not considered for the starting materials (Mittal et al. 2011). The comparable behavior of cell I and cell $\mathrm{IV}_{\mathrm{I}}$ could be because of the structures of cell $\mathrm{IV}_{\mathrm{I}}$ and cell I are so similar (Wada et al. 2004).

The behaviors of various crystalline celluloses are seen to depend on the initial hydrolysis reactions. Given that the interconversion processes for some celluloses are most probably independent of the enzyme reaction, thus, the trends of total sugar productions are most likely due to intrinsic properties of the starting materials. 


\section{Concluding Remarks}

242 In order to enhance enzymatic hydrolysis sugar production, various forms of crystalline celluloses were

243 used as the starting materials. The modification of cellulose crystalline structures somehow assists the enzyme

244 to perform better during hydrolysis reaction, although interconversion processes of the celluloses have taken

245 place. In addition, considering constant DP for starting materials was necessary to improve the evaluation of

246 enzymatic treatment of the various cellulose forms. From the results above, it is concluded that enzymatic

247 hydrolysis treatment is better for cell III I $_{I}$ and group II celluloses, compared to native cellulose. Thus a

248 recommendation can be made to either convert cell I into cell $\mathrm{III}_{\mathrm{I}}$ or group II celluloses for enzymatic hydrolysis.

249 Acknowledgement

250 The authors are thankful for the support that was given by the Kyoto University Global GCOE program of 'Energy Science in the Age of Global Warming', for the completion of this work.

252

253

254

255

256

257

258

259

260

261

262

263

264

265

266

267

268

269

270

271

272

273

274

275

276

277 


\section{References}

Abdullah R, Ueda K, Saka S (2013) Decomposition behaviors of various crystalline celluloses as treated by semi-flow hot-compressed water. Cellulose 20:2321-2333

Andersson S, Serimaa R, Paakkari T, Saranpää P, Pesonen E (2003) Crystallinity of wood and the size of cellulose crystallites in Norway spruce (Picea abies). J. Wood Sci. 49:531-537

Beckham GT, Matthews JF, Peters B, Bomble YJ, Himmel ME, Crowley MF (2011) Molecular-level origins of biomass recalcitrance: Decrystallization free energies for four common cellulose polymorphs. J. Phys. Chem. B 115:4118-4127

Bommarius A, Katona A, Cheben SE, Patel AS, Ragauskas AJ, Knudson K, Pu Y (2008) Cellulase kinetics as a function of cellulose pretreatment. Metab. Eng. 10:370-381

Cao Y, Tan H (2002) Effects of cellulase on the modification of cellulose. Carbohydr. Res. 337:1291-1296

Cao Y, Tan H (2005) Study on crystal structures of enzyme-hydrolyzed cellulosic materials by X-ray diffraction. Enzyme Microb. Technol. 36:314-317

Divne C, Ståhlberg J, Teeri TT, Jones TA (1998) High-resolution crystal structures reveal how a cellulose chain is bound in the $50 \AA$ long tunnel of cellobiohydrolase I from Trichoderma reesei. J. Mol. Biol. 275:309325

Evans R, Wearne RH, Adrian FA (1989) Molecular weight distribution of cellulose as its tricarbanilate by high performance size exclusion chromatography. J. Appl. Polym. Sci. 37:3291-3303

Fan LT, Lee YH, Beardmore DH (1980) Mechanism of the enzymatic hydrolysis of cellulose: effect of major structural features of cellulose on enzymatic hydrolysis. Biotechnol. Bioeng. 23:177-199

French AD (2014) Idealized powder diffraction patterns for cellulose polymorphs. Cellulose 21:885-896

French AD and Cintrón MS (2013). Cellulose polymorphy, crystallite size, and the Segal crystallinity index. Cellulose 20:583-588

Hall M, Bansal P, Lee JH, Realff MJ, Bommarius AS (2010) Cellulose crystallinity - a key predictor of the enzymatic hydrolysis rate. J. FEBS 277:1571-1582

Hsu T-A (1996) Pretreatment of biomass. In: Wyman CE (ed) Handbook on bioethanol: production and utilization. Taylor and Francis, Bristol, pp179-195

Igarashi K, Wada M, Hori R, Samejima M (2006) Surface density of cellobiohydrolase on crystalline celluloses - a critical parameter to evaluate enzymatic kinetics at a solid-liquid interface. FEBS J. 273:2869-2878

Igarashi K, Wada M, Samejima M (2007) Activation of crystalline cellulose to cellulose III $_{\text {I }}$ results in efficient hydrolysis by cellobiohydrolase. FEBS J. 274:1785-1792

Isogai A, Atalla RH (1998) Dissolution of cellulose in aqueous NaOH solutions. Cellulose 5:309-319

Kadam KL, Rydholm EC, McMillan JD (2004) Development and validation of a kinetic model for enzymatic saccharification of lignocellulosic. Biotechnol. Progr. 20:698-705

Kumar S, Gupta R, Lee YY, Gupta RB (2010) Cellulose pretreatment in subcritical water: Effect of temperature on molecular structure and enzymatic reactivity. Bioresour. Technol. 101:1337-1347

Langan P, Nishiyama Y, Chanzy H (2001) X-ray Structure of mercerized cellulose II at $1 \AA$ resolution. Biomacromolecules 2:410-416

Lee SB, Kim IH, Ryu DDY, Taguchi H (1983) Structural properties of cellulose and cellulase reaction mechanism. Biotechnol. Bioeng. 25:33-51 
318 Loeb L, Segal L (1955) Studies of the ethylenediamine-cellulose complex. I. Decomposition of the complex by

319 solvents. J. Polym. Sci. 15:343-354

320 Lokhande HT, Shukla SR, Chidambareswaran PK, Patil NB (1977) Ethylenediamine-induced conversion of cellulose I to cellulose III. J. Polym. Sci. Polym. Lett. Ed. 15:97-99

322

Mormann W, Michel U (2002) Improved synthesis of cellulose carbamates without by-products. Carbohydr. Polym. 50:201-208

Mittal A, Katahira R, Himmel ME, Johnson DK (2011) Effects of alkaline or liquid-ammonia treatment on crystalline cellulose: changes in crystalline structure and effects on enzymatic digestibility. Biotechnol. Biofuels 4/41:1-16

Nishimura H, Sarko A (1987) Mercerization of cellulose. IV. Mechanism of mercerization and crystallite sizes. J. Appl. Polym. Sci. 33:867-874

O’Sullivan AC (1997) Cellulose: the structure slowly unravels. Cellulose 4:173-207

330 Park S, Baker JO, Himmel ME, Parilla PA, Johnson DK (2010) Cellulose crystallinity index: measurement techniques and their impact on interpreting cellulase performance. Biotechnol. Biofuels 3/10:1-10

Puri VP (1984) Effect of crystallinity and degree of polymerization of cellulose on enzymatic saccharification. Biotechnol. Bioeng. 26:1219-1222

Reese ET, Segal L, Tripp VW (1957) The effect of cellulose on the degree of polymerization of cellulose and hydrocellulose. Text. Res. J. 27:626-632

Sasaki T, Tanaka T, Nanbu N, Sato Y, Kainuma K (1979) Correlation between X-ray diffraction measurements of cellulose crystalline structure and the susceptibility to microbial cellulose. Biotechnol. Bioeng. 21:10311042

Schacht C, Zetzl C, Brunner G (2008) From plant materials to ethanol by means of supercritical fluid technology. J Supercrit. Fluids 46:299-321

Sulzenbacher G, Schülein M, Davies GJ (1997) Structure of the endoglucanase I from Fusarium oxysporum: native, cellobiose, and 3,4-epoxybutyl $\beta$-D-cellobioside-inhibited forms, at $2.3 \AA$ resolution. Biochemistry $36: 5902-5911$

TAPPI Standard Methods T222 om-88 (1988)

Vanderghem C, Boquel P, Blecker C, Paquot M (2010) A multistage process to enhance cellobiose production from cellulosic materials. Appl. Biochem. Biotechnol. 160:2300-2307

Wada M, Chanzy H, Nishiyama Y, Langan P (2004) Cellulose III I crystal structure and hydrogen bonding by synchrotron X-ray and neutron fiber diffraction. Macromolecules 37:8548-8555

Wada M, Kwon GJ, Nishiyama Y (2008) Structure and thermal behavior of a cellulose I-ethylenediamine complex. Biomacromolecules 9:2898-2904

Wada M, Ike M, Tokuyasu K (2010) Enzymatic hydrolysis of cellulose I is greatly accelerated via its conversion to the cellulose II hydrate form. Polym. Degrad. Stab. 95:543-548

Ward RJ (2011) Cellulase engineering for biomass saccharification. In: Buckeridge MS, Goldman GH (eds) Routes to cellulosic ethanol. Springer, New York, pp135-151 cellulolytic bacteria. Appl. Environ. Microbiol. 57:3101-3106 
357 Wyk JPHV (1997) Cellulose hydrolysis and cellulase adsorption after pretreatment of cellulose materials.

$358 \quad$ Biotechnol. Tech. 11:443-335

359 Yang J, Zhang X, Yong Q, Yu S (2010) Three-stage hydrolysis to enhance enzymatic saccharifcation of steam360 exploded corn stover. Bioresour. Technol. 101:4930-4935

361 Yoshida M, Liu Y, Uchida S, Kawarada K, Ukagami Y, Ichinose H, Kaneko S, Fukuda K (2008) Effects of 362 cellulose crystallinity, hemicellulose, and lignin on the enzymatic hydrolysis of Miscanthus sinensis to 363 monosaccharides. Biosci. Biotechnol. Biochem. 72:805-810 


\section{List of figure captions}

412

413 Fig. 1 The XRD patterns of various crystalline celluloses prepared in this study

414 Fig. 2 The residues obtained from various crystalline celluloses after enzymatic hydrolysis

415 Fig. 3 The XRD patterns of group I celluloses; cell I (left), cell III (middle), cell $\mathrm{IV}_{\mathrm{I}}(r i g h t)$, after enzymatic $416 \quad$ hydrolysis

417 Fig. 4 The XRD patterns for group II celluloses; cell II (left), cell IIIII (middle), cell IV ${ }_{\text {II }}$ (right), after 418 enzymatic hydrolysis

419 Fig. 5 The comparison between XRD patterns of residues from cell $\mathrm{III}_{\mathrm{I}}$ when treated with and without 420 enzyme

421 Fig. 6 The changes in DP and crystallinity of various crystalline cellulose after enzymatic hydrolysis

422 Fig. 7 The changes in DP and hydrolyzed cellulose of various crystalline celluloses after enzymatic 423 hydrolysis

424 Fig. 8 The yield of total sugars from various crystalline celluloses after enzymatic hydrolysis 425 

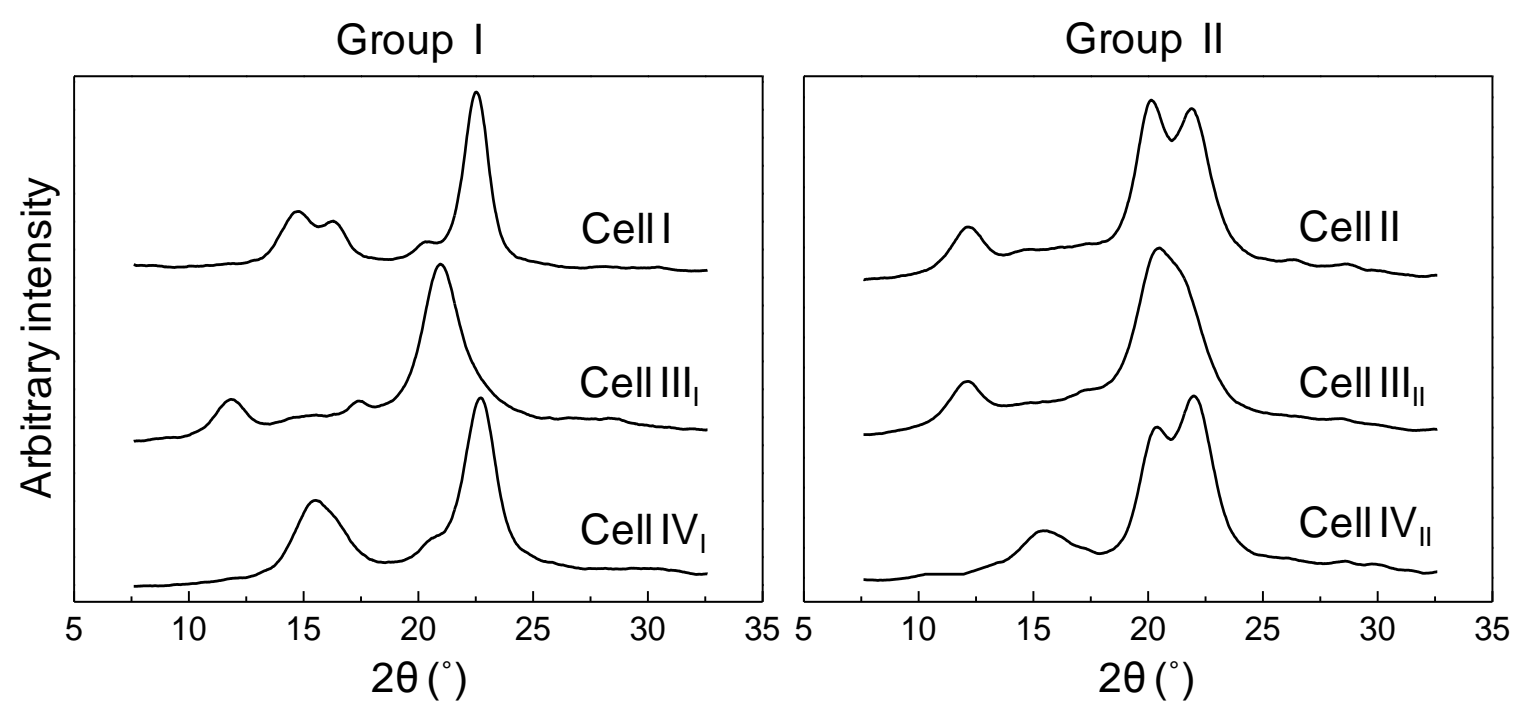

Fig. 1 The XRD patterns of various crystalline celluloses prepared in this study 


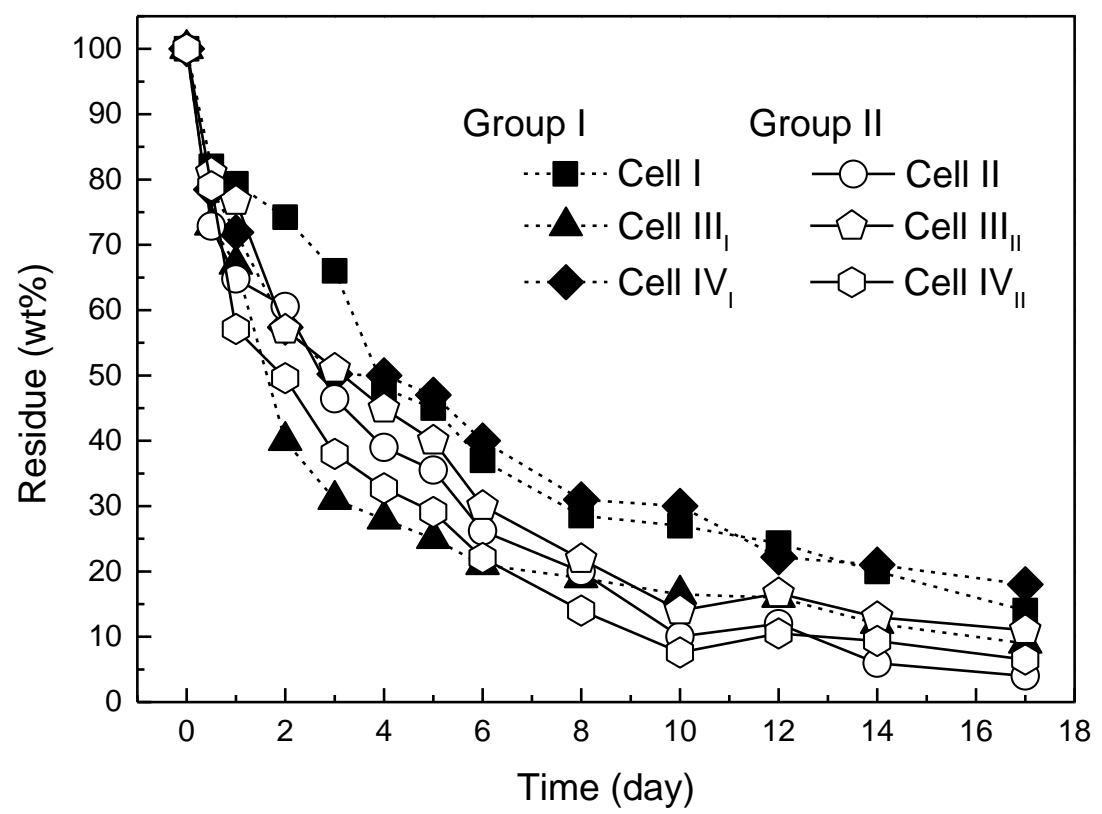

Fig. 2 The residues obtained from various crystalline celluloses after enzymatic hydrolysis 

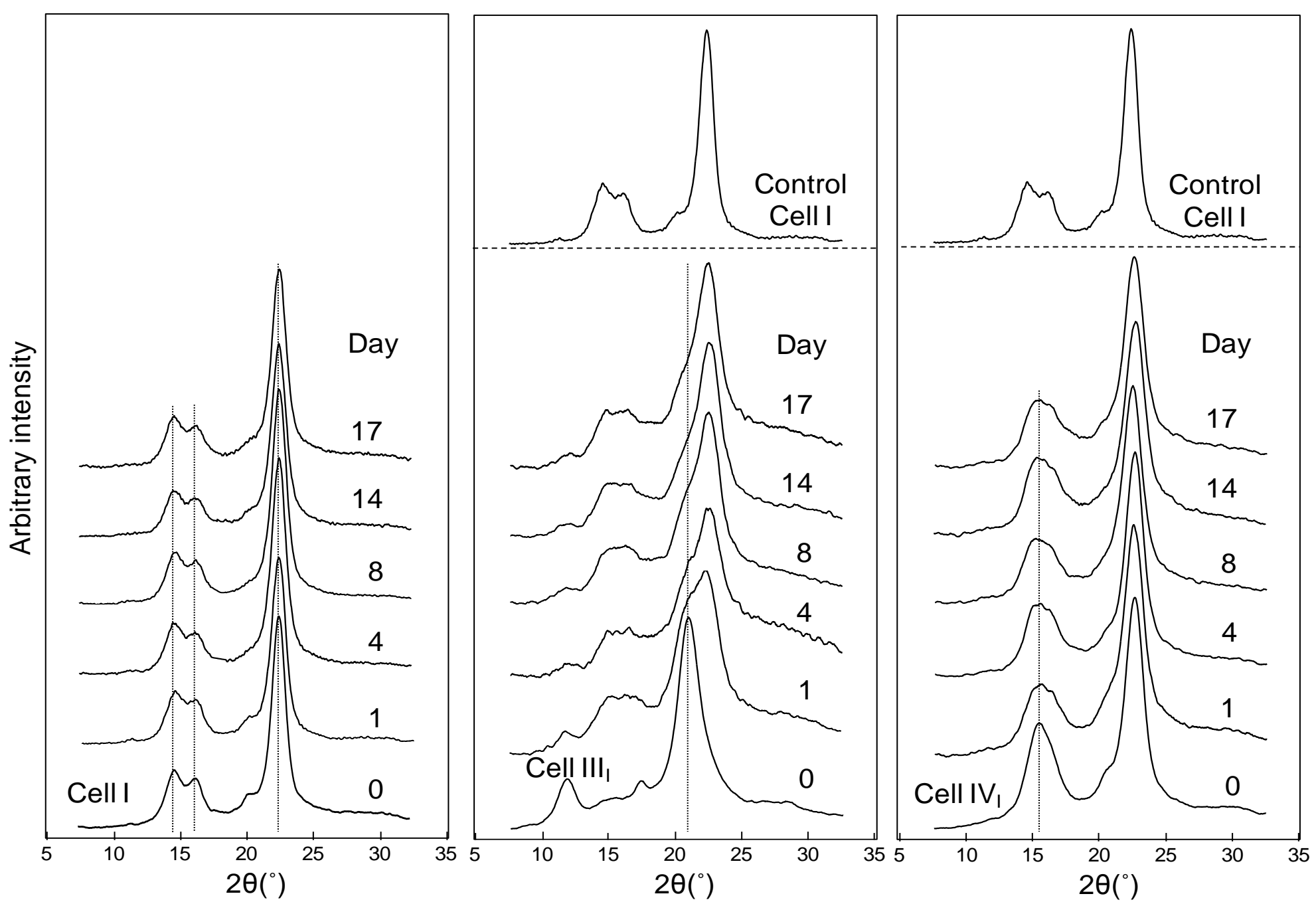

Fig. 3 The XRD patterns of group I celluloses; cell I (left), cell $\mathrm{III}_{\mathrm{I}}$ (middle), cell $\mathrm{IV}_{\mathrm{I}}($ right), after enzymatic hydrolysis 


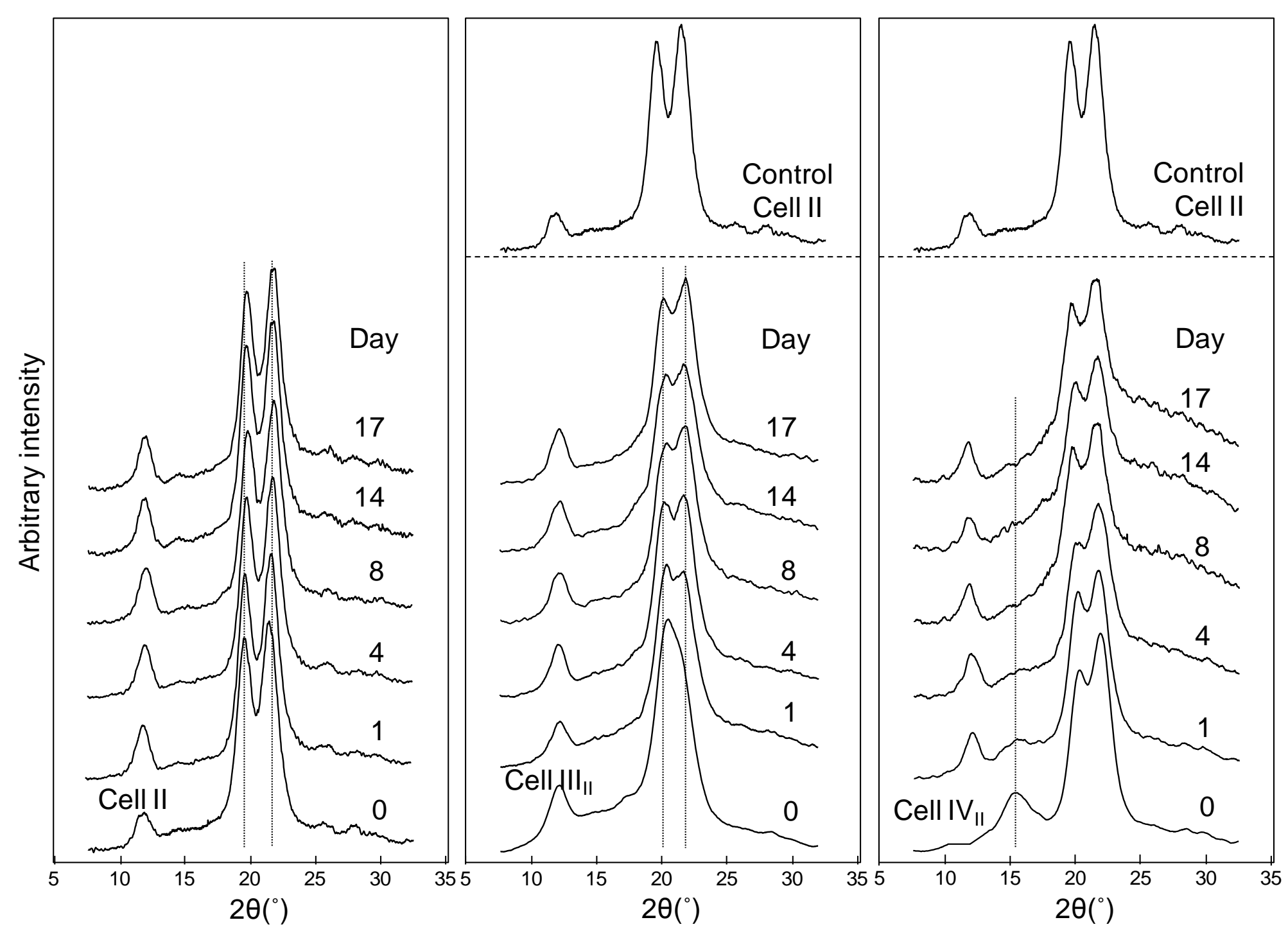

Fig. 4 The XRD patterns for group II celluloses; cell II (left), cell IIIII (middle), cell IV $\mathrm{V}_{\text {II }}(r i g h t)$, after enzymatic hydrolysis 

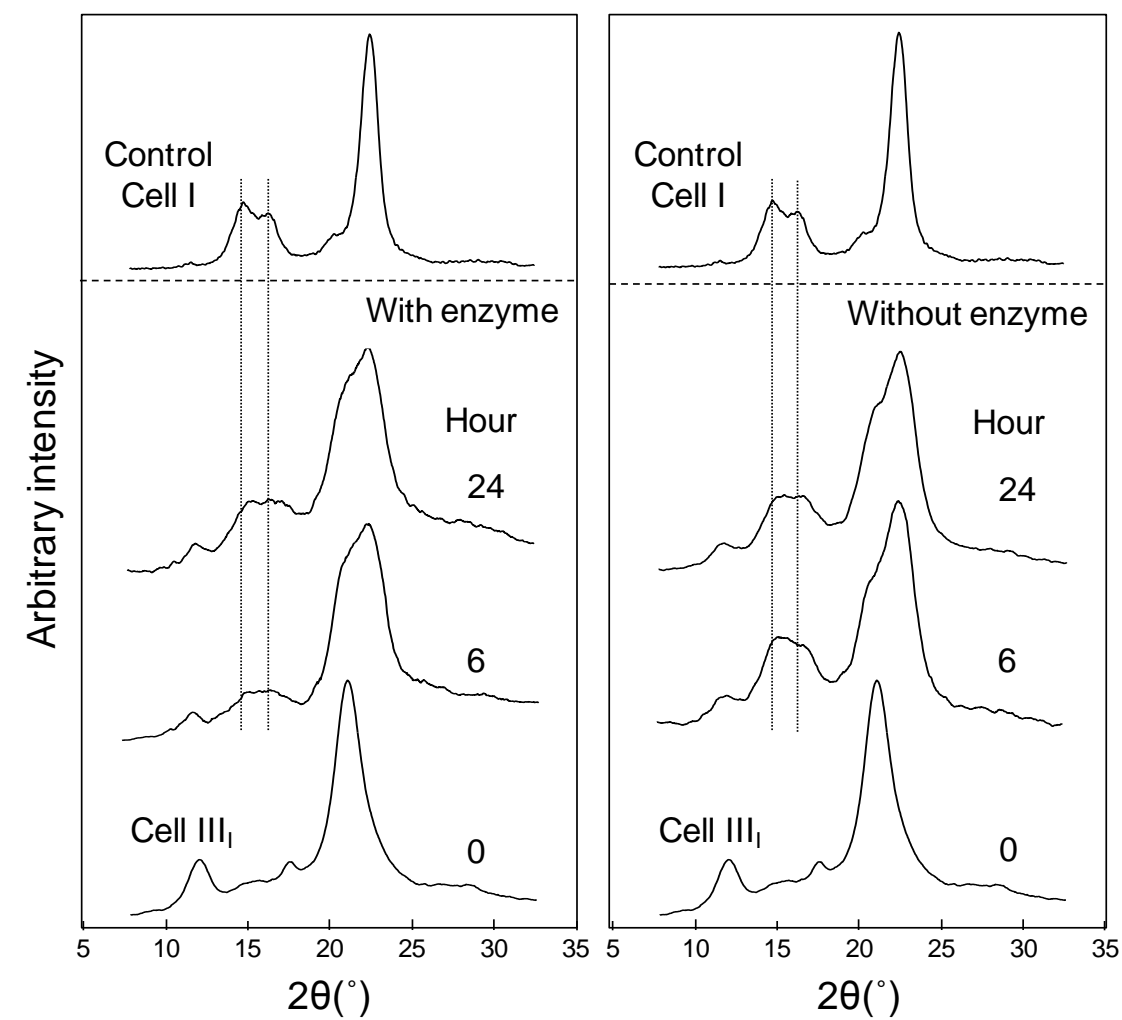

Fig. 5 The comparison between XRD patterns of residues from cell $\mathrm{III}_{\mathrm{I}}$ when treated with and without enzyme 


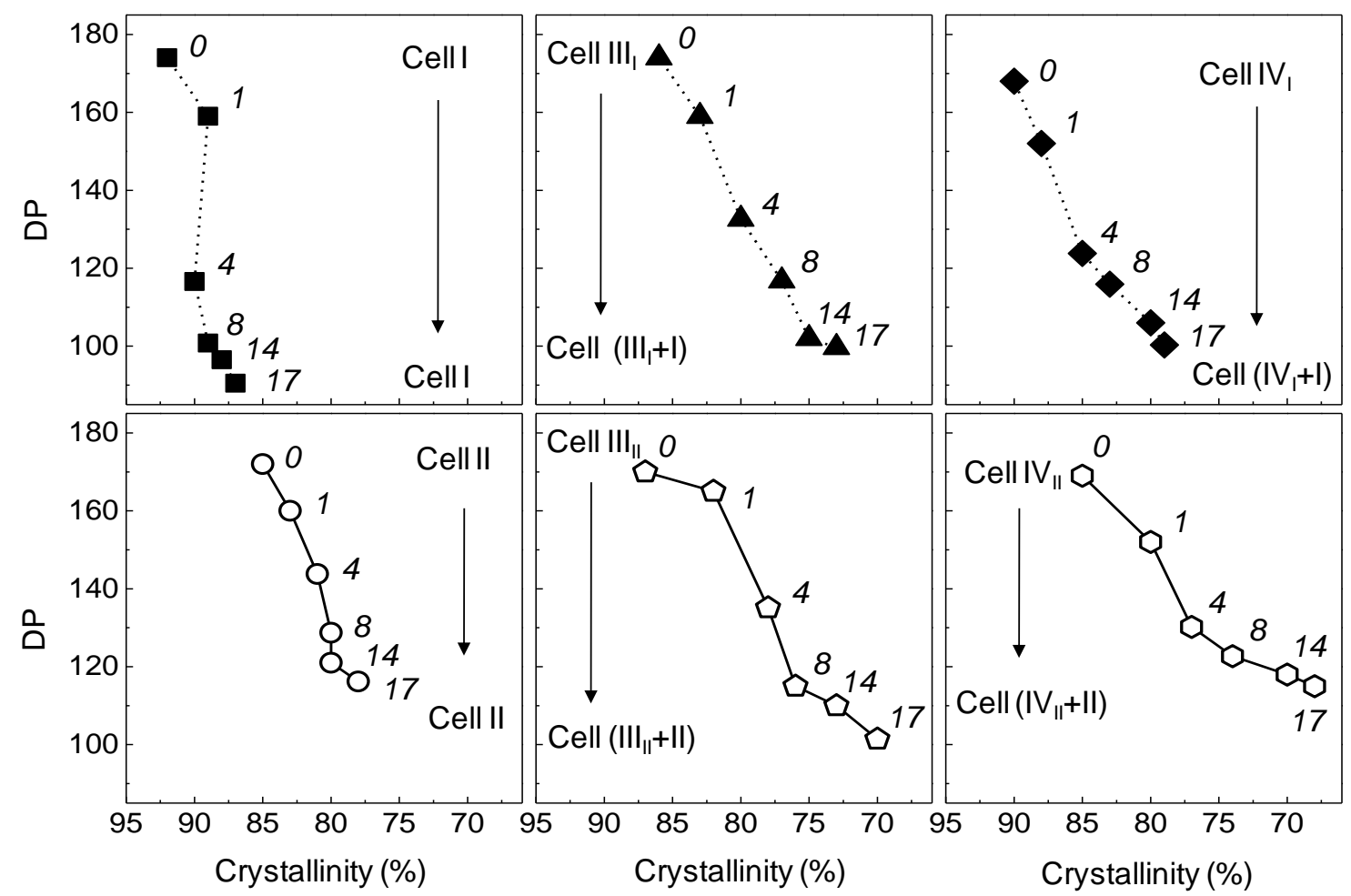

Fig. 6 The changes in DP and crystallinity of various crystalline cellulose after enzymatic hydrolysis 


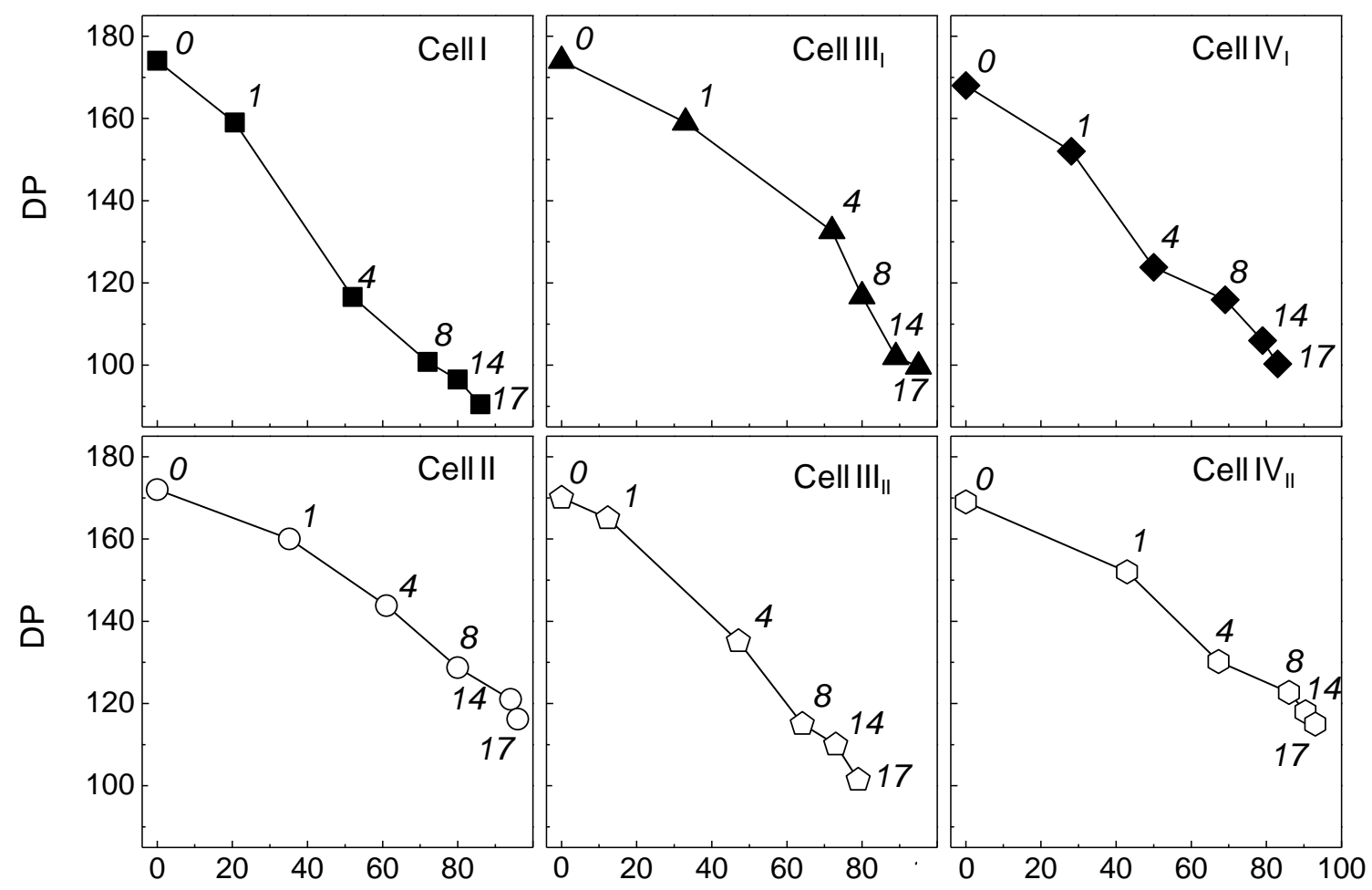

Hydrolyzedcellulose (wt\%) Hydrolyzed cellulose (wt\%) Hydrolyzed cellulose (wt\%)

Fig. 7 The changes in DP and hydrolyzed cellulose of various crystalline celluloses after enzymatic hydrolysis 


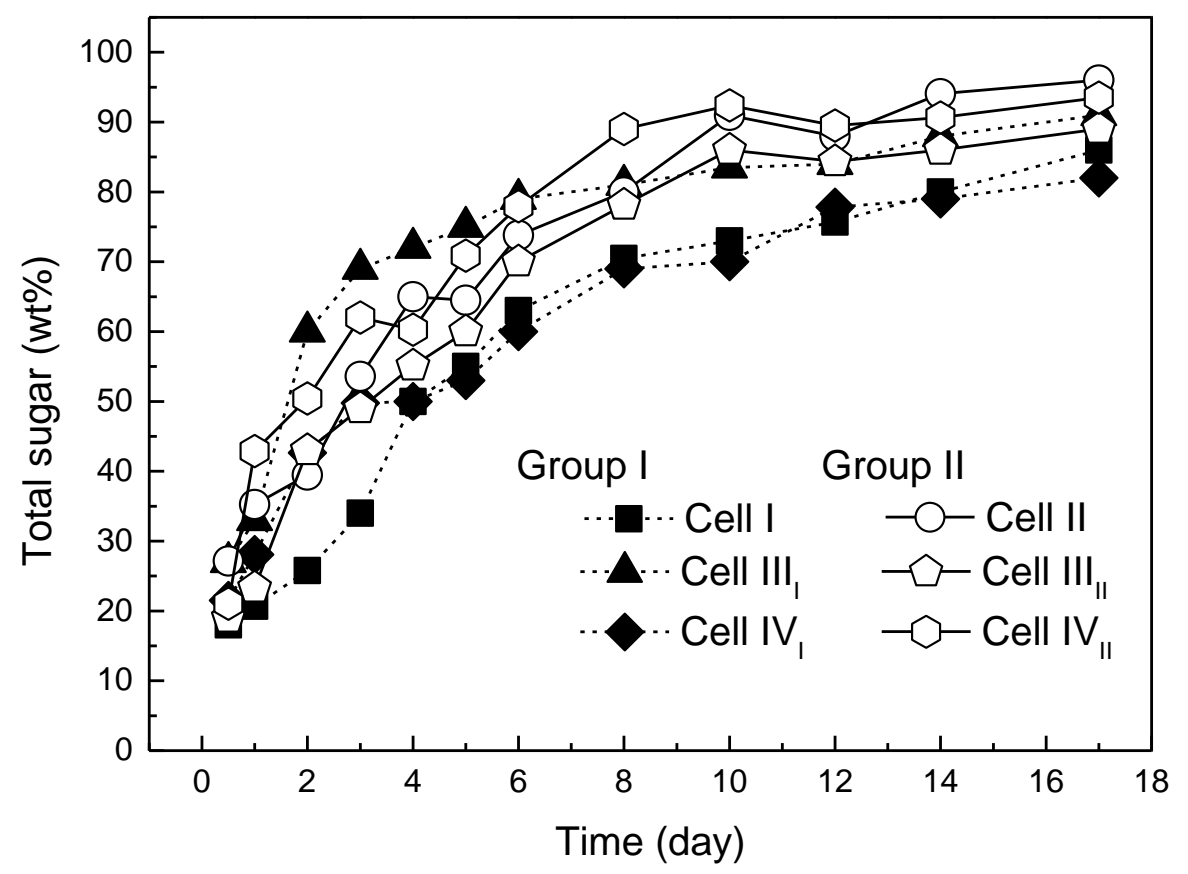

Fig. 8 The yield of total sugars from various crystalline celluloses after enzymatic hydrolysis 
Table 1 The DP and crystallinity of various crystalline celluloses as starting materials

\begin{tabular}{cccc}
\hline & Cell & DP & Crystallinity (\%) \\
\hline \multirow{3}{*}{ Group I } & I & 174 & 91.8 \\
& III $_{\text {I }}$ & 174 & 86.0 \\
& IV $_{\text {I }}$ & 168 & 89.6 \\
\hline \multirow{3}{*}{ Group II } & II & 172 & 85.3 \\
& III $_{\text {II }}$ & 170 & 87.2 \\
& IV $_{\text {II }}$ & 169 & 85.0 \\
\hline
\end{tabular}


Table 2 The pwhm, crystallite size and crystallinity of the simulated various celluloses

\begin{tabular}{ccccc}
\hline & Cell & Input pwhm $\left({ }^{\circ}\right)^{\mathrm{a}}$ & $\tau$, crystallite size $(\AA)^{\mathrm{b}}$ & Crystallinity $(\%)$ \\
\hline \multirow{3}{*}{ Group I } & I & 1.3 & 69.3 & 86.4 \\
& III $_{\mathrm{I}}$ & 2.5 & 35.9 & 89.7 \\
& IV $_{\mathrm{I}}$ & 1.8 & 50.0 & 90.1 \\
\hline \multirow{3}{*}{ Group II } & II & 1.8 & 49.8 & 83.5 \\
& III $_{\text {II }}$ & 3.5 & 25.6 & 85.3 \\
& IV $_{\text {II }}$ & 1.3 & 69.0 & 76.2 \\
\hline
\end{tabular}

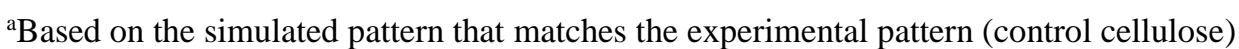

${ }^{\mathrm{b}}$ Estimated using Scherrer equation with $K=1$ 